IP Periodica Polytechnica Civil Engineering

\author{
60(1), pp. 113 126 2016 \\ DOI: $10.3311 /$ PPci.7706 \\ Creative Commons Attribution (1) \\ RESEARCH ARTICLE
}

\section{Considerations on the Pushover Analysis of Multi-Story Steel Plate Shear Wall Structures}

\author{
Masoumeh Gholipour, Mohammad Mehdi Alinia
}

Received 15-09-2014, revised 08-06-2015, accepted 08-06-2015

\begin{abstract}
Pushover analysis is frequently utilized to predict nonlinear behavior of structural systems. One important factor, which considerably influences the results of pushover analysis, is the pattern of distribution of lateral loads along the height of structures. In this paper, five 4- to 13-story SPSW frames are designed according to the AISC-341 code. The frames are then analyzed under two lateral loading patterns recommended by FEMA-356. The first load distribution pattern is proportional to the shape of the fundamental mode, called the triangular loading pattern. The second pattern is a uniform distribution in proportion to the total mass of each story level. Results show that the uniform loading pattern provides higher lateral stiffness and ultimate load carrying capacity of SPSW frames in comparison to those obtained from the triangular loading pattern. The discrepancy between the results of the two loading patterns increases with the number of story levels.
\end{abstract}

\section{Keywords}

Steel plate shear walls $\cdot$ pushover analysis $\cdot$ lateral loading pattern

\section{Masoumeh Gholipour}

Department of Civil Engineering, Amirkabir University of Technology, 424 Hafez Ave., Tehran 15875-4413, Iran

e-mail: Gholipour_m@aut.ac.ir

\section{Mohammad Mehdi Alinia}

Department of Civil Engineering, Amirkabir University of Technology, 424 Hafez Ave., Tehran 15875-4413, Iran

e-mail:m.alinia@aut.ac.ir.

\section{Introduction}

In the past three decades, the steel plate shear wall (SPSW) configuration has been widely used as a lateral load resisting system in the regions of high seismicity. A typical SPSW consists of infill steel plates connected to the beams, known as the horizontal boundary elements (HBE); and to the columns, as the vertical boundary elements (VBE). All HBE-VBE connections are of moment resisting type.

Many numerical researches have been and are being carried out to study the behavior of SPSW systems via the four available methods of analysis. Two methods are linear, known as Linear Static Procedure (LSP) and Linear Dynamic Procedure (LDP); and two methods are nonlinear, known as Nonlinear Static Procedure (NSP) and Nonlinear Dynamic Procedure (NDP). The linear procedures are appropriate when the expected level of nonlinearity is low. In the SPSW system, the material nonlinearity is considerable as infill plates yield extensively. Therefore, nonlinear methods are proper tools to study the seismic behavior of such system. The nonlinear dynamic procedure, also known as the nonlinear time history analysis, is deemed to be the most accurate method; but it is complex, expensive and time consuming, especially when there are a large number of elements involved. On the other hand, the nonlinear static procedure, known as the pushover analysis, is a more convenient available method to the structural engineers; and is favored by practicing engineers. The nonlinear pushover analysis accounts for both geometric and material nonlinearities in buildings subjected to seismic loads. It also allows the tracing of the sequence of yielding and failure of members, as well as the progress of overall capacity of structures. On the other hand, prior to a cyclic test or analysis, pushover analyses are performed to predict the maximum strength and deformations of structures in order to develop a suitable loading history, evaluate the needs for instrumentation, establish the range of load and deformation measurements, and reduce the risk of unexpected behavior during experiments [1].

In addition to the above mentioned applications, the pushover analysis has two further use in SPSW structures. According to the specifications of AISC-341 [2], Comm. F5., 3. Analysis, 
the nonlinear pushover analysis is recognized for the determination of the design forces of VBEs according to the capacity design requirements. In conventional design of SPSWs, it is assumed that the full story shear is resisted by infill plates. HBEs and VBEs are then designed according to the thickness of infill plates. Upon the completion of the preliminary design of a SPSW structure, a pushover analysis can be performed to determine the portion of story shear carried by VBEs. Subsequently, it is possible to revise the infill plate thickness accordingly.

The pushover analysis has been frequently used by researchers to investigate the nonlinear behavior of various structural systems. For SPSW systems, Shishkin et al. [3] studied the behavior of 1-, 4- and 15-story SPSW structures using the strip method modeling technique and the pushover analysis. The evaluation of M-PFI design methodology was performed by Kharrazi et al. [4] using the pushover analysis of 3-, 9- and 27-story SPSW structures. Kulak et al. [5] utilized the pushover analysis to determine the inelastic response and evaluate the drift demand of an 8-story SPSW structure. Shishkin et al. [6] used the pushover analysis to predict the inelastic behavior of SPSW test specimens. Choi and Park [7] and Park et al. [8] performed pushover analyses to obtain the yield displacements of SPSW structures in order to develop loading histories required for their test specimens.

In accordance with the above mentioned literature, the pushover analysis is utilized in the present study to analyze the behavior of multi-story SPSW frames. In a pushover analysis, the model is subjected to monotonically increasing lateral loads representing the inertia forces of an earthquake. One important factor, which considerably influences the results of pushover analysis, is the pattern of distribution of lateral loads along the height of structure. Inel et al. [9] and Kalkan and Kunnath [10] conducted studies on respectively 3-, 9-tory and 6-, 13-story steel moment resisting frames using various lateral load patterns in the pushover analyses. Similar studies were reported on reinforced concrete moment resisting frames [11,-14] and dual (wall-frame) systems [13]. To the authors' knowledge, there has been no similar study on SPSW systems.

The main objective of the present study is to demonstrate and clarify the sensitivity of the SPSW pushover analysis response to the lateral load distribution pattern. The study is performed on SPSWs having different story levels to investigate the effect of the height of SPSW structural system. Five medium- to highrise SPSW frames having 4, 7, 10 and 13 stories are designed and analyzed. Each frame is analyzed under the two lateral load distribution patterns specified in FEMA-356 [15]. Specific results regarding the structural characteristics, such as load carrying capacity; stiffness; yielding sequence; deformation mode; distribution of story shear between infill plates and VBEs; ductility; response modification and overstrength factors; and the axial forces in the VBEs are extracted from the pushover analyses and discussed.

\section{Lateral load distribution patterns}

According to the requirements of FEMA-356 [15], at least two vertical distributions of lateral loads should be considered in the pushover analyses. The two recommended patterns represent the lower and upper bounds for inertia force distributions to predict the likely variations on overall structural behavior and local demands.

The first pattern is proportional to the values of $C_{v x}$ given in the ASCE 7-10 [16]. $C_{v x}$ is the vertical distribution factor used in the equivalent lateral force procedure to determine the lateral seismic force $\left(F_{x}\right)$ induced at each story level of the structure. $F_{x}$ and $C_{v x}$ are determined according to Eqs. (1) and (2), respectively.

$$
\begin{gathered}
F_{x}=C_{v x} \cdot V \\
C_{v x}=\frac{w_{x} h_{x}^{k}}{\sum_{i=1}^{n} w_{i} h_{i}^{k}}
\end{gathered}
$$

where, $V$ is the total design lateral force or shear at the base of the structure. $w_{i}$ and $w_{x}$, are the portion of total effective weight located at level $i$ or $x ; h_{i}$ and $h_{x}$, are the height from the base to level $i$ or $x$; and $k$ is an exponent related to the structure period.

In this study, the calculation of design seismic base shear and the distribution of design seismic forces along the height of structures are carried out according to the equivalent lateral force procedure specified in the ASCE 7-10 [16]. Hence, the first lateral loading pattern is similar to the pattern utilized in design. $C_{v x}$ is meant to simulate the first mode characteristics, and thus it results in an inverted triangular distribution pattern of seismic forces as shown in Fig. 17. This loading pattern is called the Triangular Loading (TL). Also, the design performed according to the code specified triangular lateral load distribution pattern will be called the Triangular Design (TD). The triangular loading pattern was utilized in the pushover analyses of SPSW frames performed in references [3-5].

The second pattern is the uniform distribution of lateral loads which are proportional to the total mass of each story level. With the assumption of equal masses at each story level, the second pattern is called the Uniform Loading (UL), see Fig. 1p. This pattern was previously utilized by Behbahanifard et al. [17] in the pushover analysis of a 3- and a 4-story SPSW structures. The authors utilized UL since their test specimens were subjected to equal horizontal loads at every story level.

Furthermore, in the present study, an alternative design procedure based on the uniform distribution of seismic forces was performed on the 7-story frame. Although this method is not recommended in the codes of practice, it is utilized to further investigate the effect of lateral load distribution pattern on the behavior of SPSWs. A design performed according to the uniform distribution pattern of lateral loads is hereafter named Uniform Design (UD). 


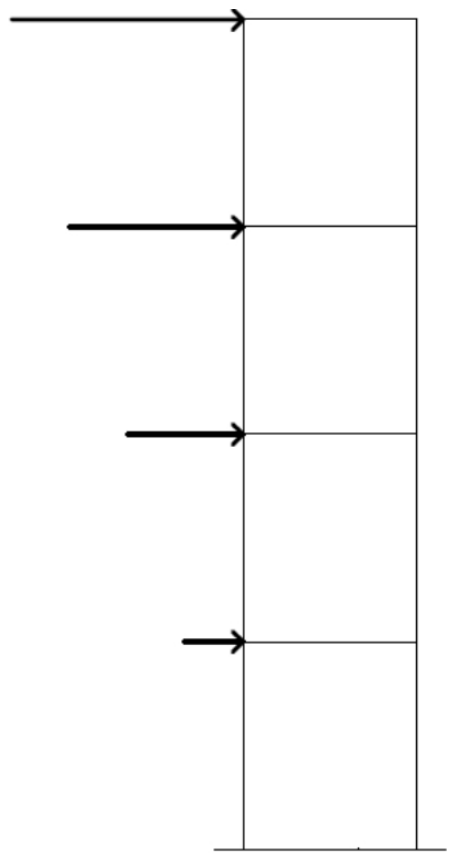

(a) Triangular Loading (TL)

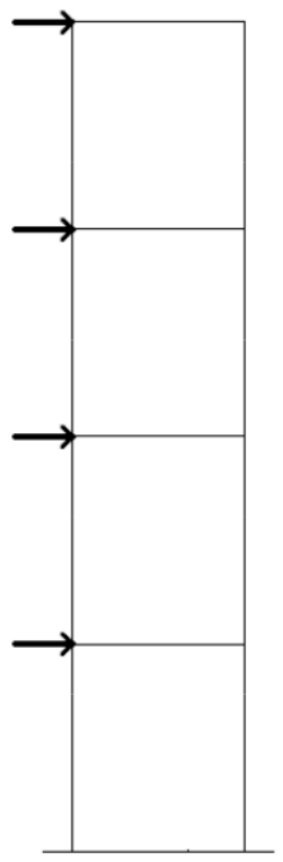

(b) Uniform Loading (UL)
Fig. 1. Lateral load distribution patterns

\section{Method of study}

\subsection{Geometric specifications of frames}

One 4-story SPSW frame, two 7-story, and one 10- and 13story SPSW frames were considered in this study. The dead, live and seismic loads were calculated for a building having the typical floor plan given in Fig. 2. The building design included two SPSWs on the perimeter in each direction. All beam-column connections were considered to be shear type, except those in the bays of SPSWs which were designed as moment resisting, according to the requirements of AISC-341 [2].

The span length of SPSWs in the studies reported by other researchers [4, 5, 18,-20] ranged from 3 to $8 \mathrm{~m}$, with the story height of 3 to $4 \mathrm{~m}$. In this research, the story height was presumed to be $3.6 \mathrm{~m}$. Considering the span length of $3 \mathrm{~m}$ in the middle span, the aspect ratio of SPSW becomes 0.83 which complies with the range of 0.8 to 2.5 , as recommended in the AISC-341 [2].

\subsection{Material properties}

The ASTM-A36 and ASTM-A572 steel material properties were respectively used for infill plates and frame members. The presumed nonlinear stress-strain characteristics of materials are given in Fig. 3. The yield stress of infill plate (325 MPa) was selected less than that of frame members (385 MPa) to reduce the forces induced by infill plates on the HBEs and VBEs.

\subsection{Design procedure}

All frames were designed according to the AISC-341 [2] and the AISC-360 [21 rules and specifications. The thickness of infill plates was calculated to resist the full story shear. HBEs and VBEs were then designed to resist forces induced by the

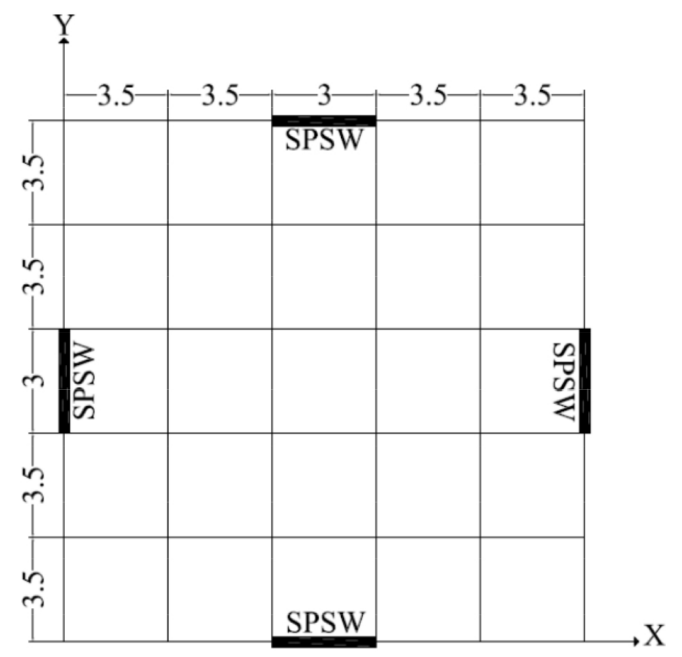

Fig. 2. Typical floor plan of studied frames

fully yielded infill plates according to the principles of capacity design method per AISC-341 [2]. The HBE-VBE moment connection details are composed of reduced beam sections (RBS) to ensure the inelastic action at HBE ends away from the face of VBEs.

The as-designed infill plate thicknesses and sections of HBEs and VBEs are given in Tables 1-5. HBEs were selected from the W-section type. VBEs were selected from box sections since $\mathrm{W}$-sections did not fulfill the capacity design requirements. The box sections are named according to their widths and thicknesses in millimeters. For example, the Box $300 \times 20$ is a square section with the width and height of $300 \mathrm{~mm}$, and web thickness of $20 \mathrm{~mm}$. It should be noted that the thicknesses of infill plates were selected as exactly calculated in the design procedures, without being rounded up or down. A similar procedure was assumed for the design of HBE and VBE sections. These assumptions were undertaken to prevent any unforeseen effects and misleading results.

Tab. 1. Design sections- 4-story frame-TD

\begin{tabular}{|c|c|c|c|}
\hline Column & Beam & Plate & Level \\
\hline BOX $300 \times 20$ & W8 $\times 58$ & $1.18 \mathrm{~mm}$ & 4 \\
\hline BOX $300 \times 30$ & W8 $\times 58$ & $2.10 \mathrm{~mm}$ & 3 \\
\hline BOX $350 \times 25$ & W8 $\times 58$ & $2.75 \mathrm{~mm}$ & 2 \\
\hline BOX $350 \times 25$ & W8 $\times 58$ & $3.10 \mathrm{~mm}$ & 1 \\
\hline
\end{tabular}

Tab. 2. Design sections- 7-story frame-TD

\begin{tabular}{|c|c|c|c|}
\hline Column & Beam & Plate & Level \\
\hline BOX $300 \times 20$ & $W 8 \times 58$ & $1.30 \mathrm{~mm}$ & 7 \\
\hline BOX $350 \times 30$ & W8 $\times 58$ & $2.50 \mathrm{~mm}$ & 6 \\
\hline BOX $450 \times 30$ & W10 × 77 & $3.55 \mathrm{~mm}$ & 5 \\
\hline BOX $450 \times 45$ & $W 10 \times 77$ & $4.40 \mathrm{~mm}$ & 4 \\
\hline BOX $500 \times 45$ & $W 10 \times 88$ & $5.05 \mathrm{~mm}$ & 3 \\
\hline BOX $500 \times 45$ & $W 10 \times 88$ & $5.42 \mathrm{~mm}$ & 2 \\
\hline BOX $500 \times 45$ & $W 10 \times 100$ & $5.80 \mathrm{~mm}$ & 1 \\
\hline
\end{tabular}


Tab. 5. Design sections- 13-story frame-TD

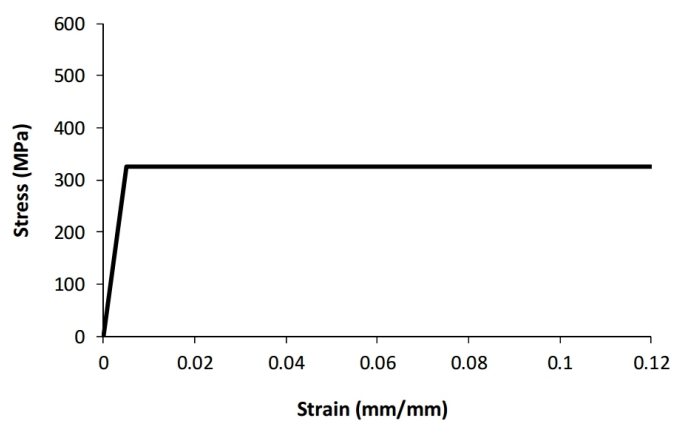

(a) Infill plates

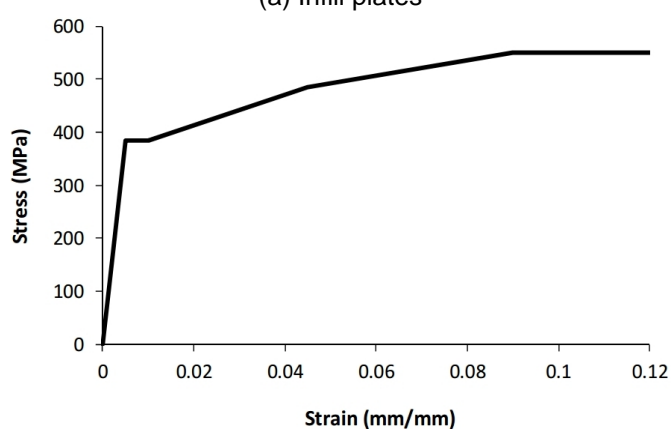

(b) Frame members

Fig. 3. Stress-strain characteristics of materials

Tab. 3. Design sections- 7-story frame-UD

\begin{tabular}{|c|c|c|c|}
\hline Column & Beam & Plate & Leve \\
\hline BOX $250 \times 20$ & $W 8 \times 40$ & $0.73 \mathrm{~mm}$ & 7 \\
\hline BOX $300 \times 25$ & $W 8 \times 40$ & $1.50 \mathrm{~mm}$ & 6 \\
\hline BOX $350 \times 30$ & $W 10 \times 68$ & $2.25 \mathrm{~mm}$ & 5 \\
\hline BOX $400 \times 35$ & $W 10 \times 68$ & $3.10 \mathrm{~mm}$ & 4 \\
\hline BOX $450 \times 35$ & $W 10 \times 88$ & $3.90 \mathrm{~mm}$ & 3 \\
\hline BOX $450 \times 40$ & $W 10 \times 88$ & $4.70 \mathrm{~mm}$ & 2 \\
\hline BOX $450 \times 40$ & $W 10 \times 112$ & $5.60 \mathrm{~mm}$ & 1 \\
\hline
\end{tabular}

Tab. 4. Design sections- 10 -story frame-TD

\begin{tabular}{|c|c|c|c|}
\hline Column & Beam & Plate & Level \\
\hline BOX $350 \times 25$ & W8 $\times 67$ & $1.43 \mathrm{~mm}$ & 10 \\
\hline BOX $450 \times 35$ & $W 10 \times 88$ & $2.80 \mathrm{~mm}$ & 9 \\
\hline BOX $550 \times 45$ & $W 10 \times 88$ & $4.15 \mathrm{~mm}$ & 8 \\
\hline BOX $650 \times 45$ & $W 10 \times 112$ & $5.40 \mathrm{~mm}$ & 7 \\
\hline BOX $650 \times 65$ & $\mathrm{~W} 10 \times 112$ & $6.40 \mathrm{~mm}$ & 6 \\
\hline BOX $750 \times 55$ & $W 12 \times 152$ & $7.40 \mathrm{~mm}$ & 5 \\
\hline BOX $750 \times 60$ & W12 × 152 & $8.00 \mathrm{~mm}$ & 4 \\
\hline BOX $750 \times 65$ & $W 12 \times 170$ & $8.50 \mathrm{~mm}$ & 3 \\
\hline BOX $750 \times 65$ & $W 12 \times 170$ & $8.80 \mathrm{~mm}$ & 2 \\
\hline BOX $750 \times 65$ & $W 12 \times 190$ & $9.10 \mathrm{~mm}$ & 1 \\
\hline
\end{tabular}

\begin{tabular}{|c|c|c|c|}
\hline Column & Beam & Plate & Level \\
\hline BOX $400 \times 30$ & W8 $\times 67$ & $1.53 \mathrm{~mm}$ & 13 \\
\hline BOX $550 \times 40$ & $W 10 \times 100$ & $3.15 \mathrm{~mm}$ & 12 \\
\hline BOX $700 \times 45$ & $W 10 \times 100$ & $4.80 \mathrm{~mm}$ & 11 \\
\hline BOX $800 \times 55$ & W10 $x$ & $6.40 \mathrm{~mm}$ & 10 \\
\hline BOX $900 \times 60$ & $W 10 \times 112$ & $7.90 \mathrm{~mm}$ & 9 \\
\hline BOX $900 \times 75$ & W12x & $9.00 \mathrm{~mm}$ & 8 \\
\hline BOX $1000 \times 70$ & $W 12 \times 170$ & $10.40 \mathrm{~mm}$ & 7 \\
\hline BOX $1000 \times 75$ & $W 12 \times 170$ & $11.20 \mathrm{~mm}$ & 6 \\
\hline BOX $1100 \times 75$ & $W 12 \times 190$ & $12.50 \mathrm{~mm}$ & 5 \\
\hline BOX $1100 \times 80$ & $W 12 \times 190$ & $13.10 \mathrm{~mm}$ & 4 \\
\hline BOX $1100 \times 80$ & $W 12 \times 190$ & $13.40 \mathrm{~mm}$ & 3 \\
\hline BOX $1100 \times 80$ & $W 12 \times 190$ & $13.60 \mathrm{~mm}$ & 2 \\
\hline BOX $1100 \times 80$ & $W 12 \times 252$ & $14.00 \mathrm{~mm}$ & 1 \\
\hline
\end{tabular}

\subsection{FE modeling}

All frames were modeled and analyzed via the ABAQUS finite element software package [22]. Infill plates, HBEs and VBEs were modeled with the shell element S4R; and the distributed plasticity approach was utilized in the analyses. According to references [17, 23], the selected modeling procedure shows high accuracy when compared to the experimental results.

To validate the modeling procedure, the 4-story SPSW frame tested by Driver et al. [24] was remodeled and analyzed. To simulate the actual experimental boundary conditions, all base nodes were restrained against displacements. VBEs base nodes were also restrained against rotations. Gravity loads of $720 \mathrm{kN}$ were applied at the top of each VBE and equal lateral loads were applied at the HBE-VBE connections. The comparison between experimental and the current FE results is shown in Fig. 4, representing the base shear variation against the $1^{s t}$ story displacement. The current FE results show a good agreement with the experiment in both elastic and inelastic stages.

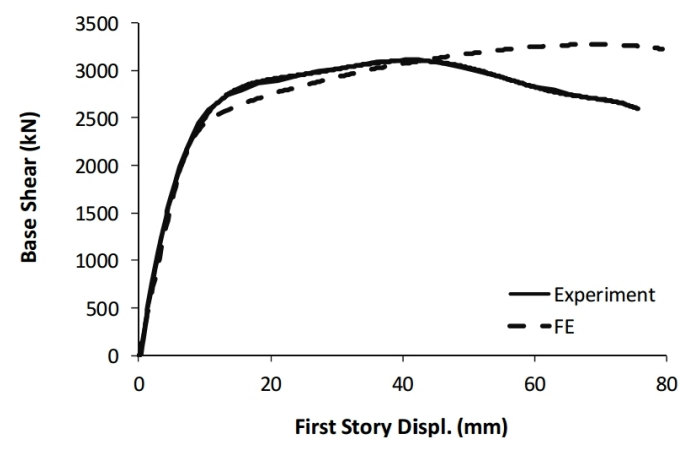

Fig. 4. Verification of FE modeling procedure

The corresponding von Mises stress distribution at the ultimate state is presented in Fig. 5. As shown, significant yielding occurred in the infill plate and VBEs of the $1^{\text {st }}$ story, which comply with the test results. 


\begin{tabular}{|l|}
\hline S, Mises \\
SNEG, (fraction $=-1.0$ ) \\
(Avg: $75 \%$ ) \\
$+4.820 \mathrm{e}+03$ \\
$+4.419 \mathrm{e}+03$ \\
$+4.018 \mathrm{e}+03$ \\
$+3.618 \mathrm{e}+03$ \\
$+3.217 \mathrm{e}+03$ \\
$+2.816 \mathrm{e}+03$ \\
$+2.415 \mathrm{e}+03$ \\
$+2.015 \mathrm{e}+03$ \\
$+1.614 \mathrm{e}+03$ \\
$+1.213 \mathrm{e}+03$ \\
$+8.124 \mathrm{e}+02$ \\
$+4.116 \mathrm{e}+02$ \\
$+1.088 \mathrm{e}+01$ \\
\hline
\end{tabular}

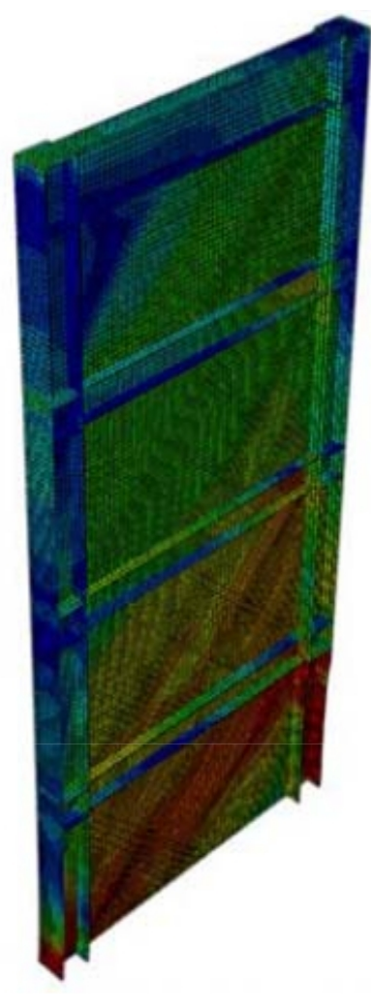

Fig. 5. Von Mises stress distribution at the ultimate state

\section{Discussion of results}

The structural characteristics of the 4- to 13-story frames under both triangular (TL) and uniform (UL) lateral loading patterns are compared and discussed in this section.

\subsection{Load carrying capacity and lateral stiffness}

The pushover and lateral stiffness curves of the 4-, 7-, 10- and 13-story SPSW frames under TL and UL patterns are presented in Fig. 6. The results correspond to frames designed according to the code specified lateral load distribution (TD) unless otherwise noted. The solid circles on the curves represent the roof displacements at which the corresponding drift angle is $2.5 \%$ as specified in ASCE 7-10 [16].

According to the results, both lateral stiffness and load carrying capacity of frames under the UL are greater than those of the TL pattern. Similar results were reported by other researchers for reinforced concrete and steel moment resisting frames in references [11-14]. To elaborate on the differences between the eight pairs of curves, the amounts of the initial stiffness and the load carrying capacities of frames at the ultimate roof displacement limits are extracted and recorded in Table 6. Accordingly, structures under UL pattern exhibit stiffer responses; and their $2.5 \%$ drift angles occur at larger roof displacements. In addition, all above mentioned differences increase with the number of stories.

The results in Table 6 also show that, in general, the initial lateral stiffness decrease with the number of story levels. With the decrease of lateral stiffness, the $2.5 \%$ drift angle, and consequently the corresponding ultimate roof displacements occur at earlier stages of loading, as depicted in Fig. 6. The result confirms the $48 \mathrm{~m}$ height limit for SPSW structures imposed by ASCE 7-10 [16].

For the typical 7-story frame, the amounts of the design story shear per ASCE 7-10 [16] (TD), along with those corresponding to the uniform load distribution design procedure (UD), are given in Table 7. The story shear forces are also given in a scaled form relative to their design base shear; as well as a graphical representation. The results in Table 7 show that the design story shear distribution in UD is always smaller than those in the TD.

On the other hand, Fig. 7 presents four pushover curves for the 7-story frame. Two curves relate to the TD frame; and two curves relate to the UD frame. Each design type frame is separately subjected to the TL and UL patterns. Therefore, the TD-UL curve relates to a frame that is designed according to the triangular load distribution pattern (TD) and analyzed under uniform loading pattern (UL). The results show that the lateral loading pattern has a considerable effect on the behavior of SPSWs in both elastic and inelastic stages. When both design and analysis loading patterns are similar; i.e. TD-TL and UD-UL, the two pushover curves become identical. It should be noted that the design base shear of both UD and TD frames are equal. In addition, the UD frame pushed under TL produced the least stiff response. This is due to the fact that the story shear at each level under the TL pattern is greater than those of the UL pattern, as previously indicated in Table 7

In general, it can be stated that since the design of SPSW structures is commonly performed according to TD, the story shear forces under UL become smaller than those under TL; and hence, the stiffness and the load carrying capacities of frames under UL are always greater than those under TL.

\subsection{Yielding sequence}

Despite the differences in the behavior of various multi-story frames under the two loading patterns, the yielding sequence was desirable in all cases. First yielding always appeared in infill plates; then plastic hinges occurred at the RBS locations of HBEs; and finally, the lower ends of VBEs yielded. The white regions in Fig. 8 depict the yielded areas of infill plates of the 7-story frame at the ultimate state. Other stories had similar patterns and are thus omitted for brevity. Under TL, the yielded areas in the upper stories are more than the lower stories; and in contrast, the pattern is reversed under UL. Similar results were obtained for other frames. The difference in the yield patterns of infill plates is attributed to the different distribution of story shear under the two loading patterns, as indicated in Table 7

\subsection{Deformation modes}

Fig. 9 depicts the lateral displacements and drifts of the four studied frames at the ultimate state. The given lateral displacements are total, and compose of both shear and flexural displacements. The curvature of a displacement curve is negative when flexure is dominant, and becomes positive when shear is dominant. 
Tab. 6. Load carrying capacities and initial stiffness of frames

\begin{tabular}{ccccccc}
\hline \multirow{2}{*}{ Model } & \multicolumn{3}{c}{ Load carrying capacity $(\mathrm{kN})$} & \multicolumn{3}{c}{ Initial stiffness $(\mathrm{kN} / \mathrm{mm})$} \\
\cline { 2 - 7 } & TL & UL & \%Diff. & TL & UL & \%Diff. \\
\hline 4-story & 1901 & 2339 & 23.04 & 28.30 & 36.48 & 28.90 \\
7-story & 3448 & 4563 & 32.34 & 19.24 & 26.47 & 37.58 \\
10-story & 5790 & 8405 & 45.16 & 17.14 & 24.59 & 43.47 \\
13-story & 7970 & 13481 & 69.15 & 16.54 & 24.15 & 46.01 \\
\hline
\end{tabular}

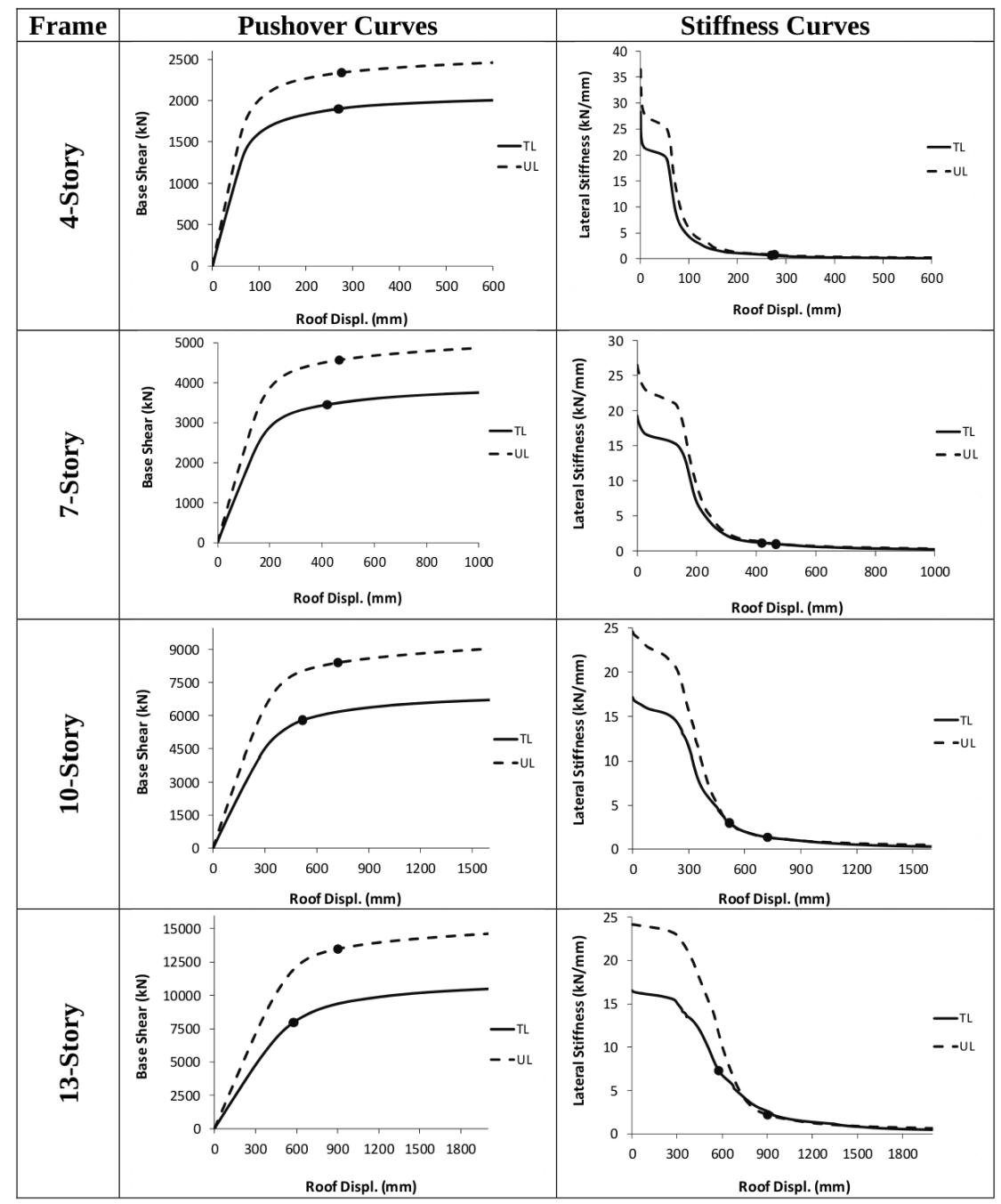

Fig. 6. Pushover and lateral stiffness curves

Tab. 7. Story shear in the 7-story frame

\begin{tabular}{|c|c|c|c|c|c|c|}
\hline \multirow{2}{*}{ Story level } & \multicolumn{2}{|c|}{ Design story shear (kN) } & \multicolumn{2}{|c|}{ Scaled story shear } & \multicolumn{2}{|c|}{ Graphical representation of story shear } \\
\hline & TD & UD & TD & UD & & \\
\hline 7 & 326 & 186 & 0.25 & 0.14 & & 6 \\
\hline 6 & 607 & 371 & 0.47 & 0.29 & & \\
\hline 5 & 841 & 557 & 0.65 & 0.43 & & $4 \frac{0}{\grave{n}}$ \\
\hline 4 & 1026 & 742 & 0.79 & 0.57 & & 2 \\
\hline 3 & 1164 & 928 & 0.9 & 0.71 & & $f_{1}$ \\
\hline 2 & 1255 & 1114 & 0.97 & 0.86 & 0.6 & 0 \\
\hline 1 & 1299 & 1299 & 1 & 1 & Story shear/Design bases shear & \\
\hline
\end{tabular}




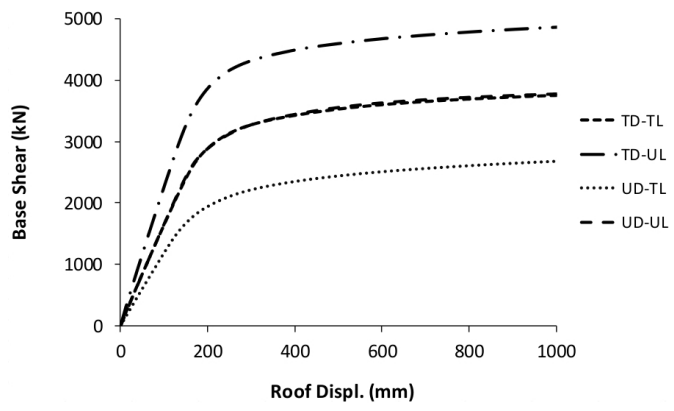

Fig. 7. Different pushover curves for the 7-story frame

The results related to TL in Fig. 9 indicate that in all but the 4story frame, a flexural deformation mode is dominant along the height of structures. In the 4-story frame, however, an inflection point (the transition from flexure-dominant to shear-dominant mode) appeared at the $3^{\text {rd }}$ story. Under UL pattern, on the other hand, all frames showed a flexure-dominant deformation mode in the lower stories and a shear-dominant deformation mode in the most of the upper stories. Inflection points are also visible in the story drift curves. When the flexure mode is dominant, the amount of story drifts increase from the lower stories upward. This case is reversed when the shear displacement is dominant.

\subsection{Distribution of story shear between infill plates and VBEs}

In each story, the total shear is jointly carried by VBEs and infill plates. In the case of the 7-story frame under UL pattern, the differential contribution of VBEs and infill plates, as well as the story shear in two typical story levels are depicted in Fig. 10 Similar curves for the 10-story frame under TL pattern are given in Fig. 11. In these figures, the vertical displacement limit line represents the $2.5 \%$ drift angle. The corresponding curves for other frames and story levels were similar and are omitted for brevity.

In general, the results indicate that in some cases the portion of either infill plate or VBEs was greater than the other throughout the loading; and in other cases, they interchanged. In the 4- and 7-story frames, the portion of infill plates in all stories was always greater than the VBEs'. In the 10-story frame under TL pattern, the portion of infill plate in the $1^{\text {st }}$ story was always less than the VBEs'. In the $2^{\text {nd }}$ story, most of the story shear was carried by the infill plate in the early stages of loading; but changed over to the VBEs at the ultimate state. In other stories, the shear portion of infill plates were always greater than the VBEs'. In the 10-story frame under UL pattern, similar results were obtained except that in the $3^{\text {rd }}$ story the shear distribution was similar to the $2^{\text {nd }}$ story.

In the 13-story frame, under TL pattern, the shear portion of infill plate in the $1^{\text {st }}$ story was less than the VBEs'. In the $13^{\text {th }}$ story, the shear portion of infill plate was more than the VBEs' in the early stages of loading. In all other stories, the story shear absorbed by infill plates and VBEs were almost equal at the early stages of loading; but at the ultimate state, the VBEs ab-

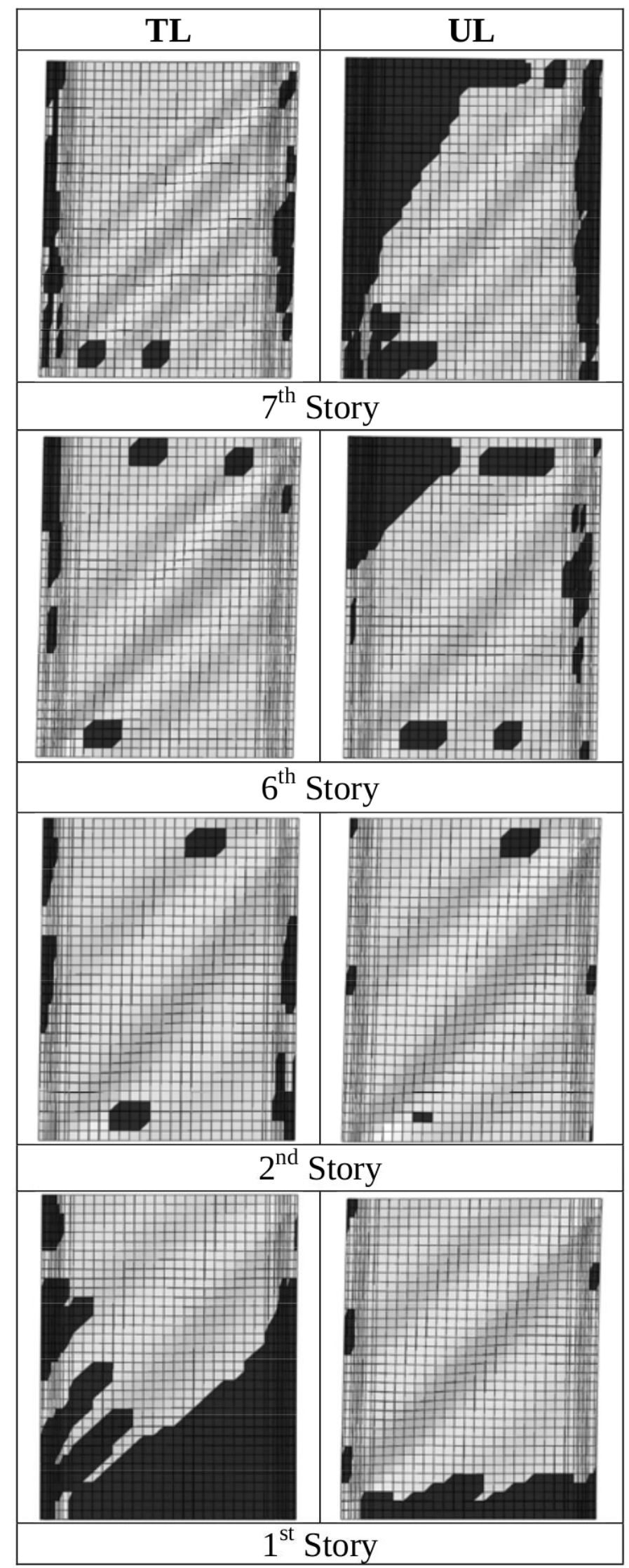

Fig. 8. Yielded areas of infill plates at the ultimate state of the 7-story frame 


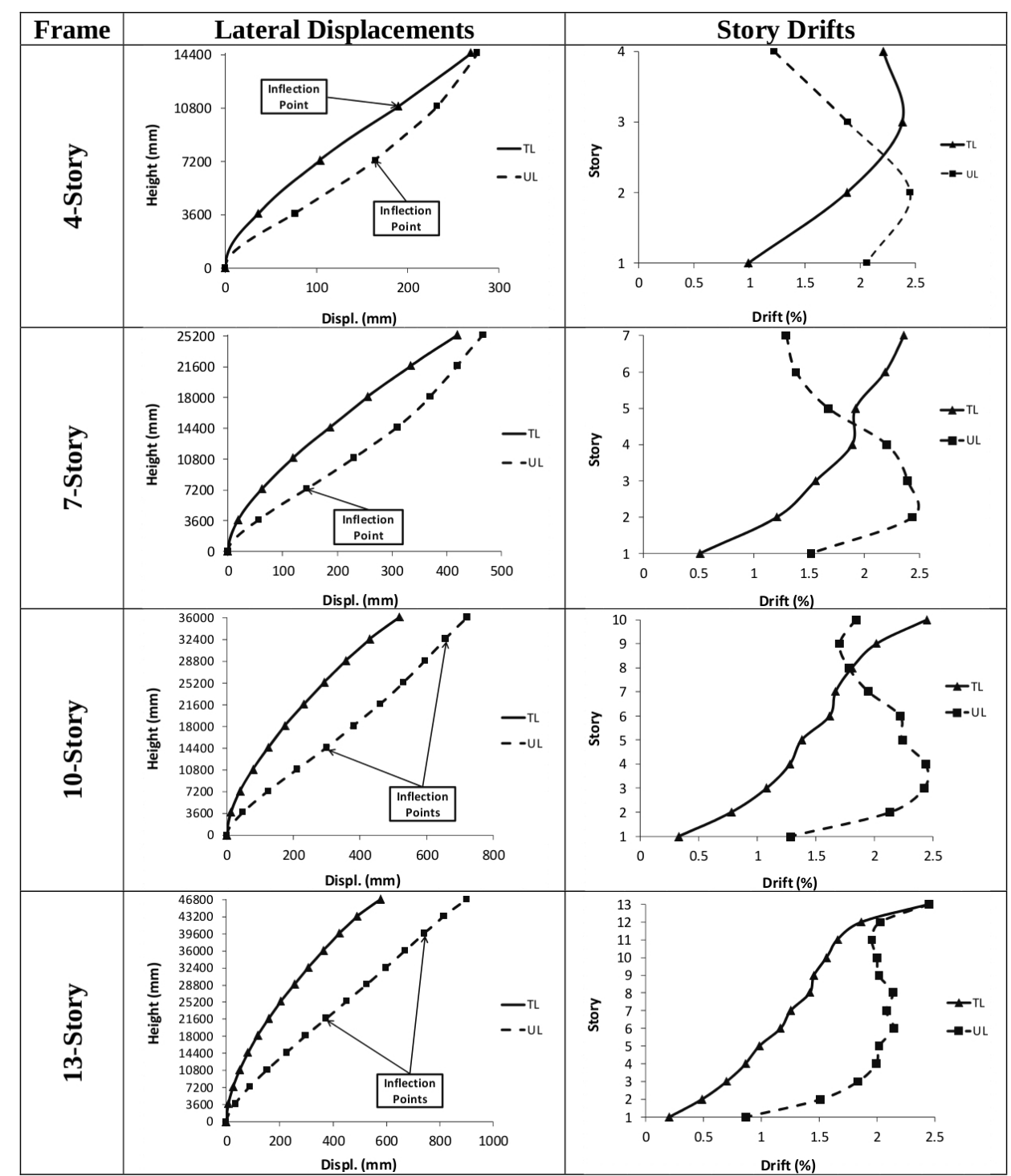

Fig. 9. Lateral displacements and story drifts at ultimate state
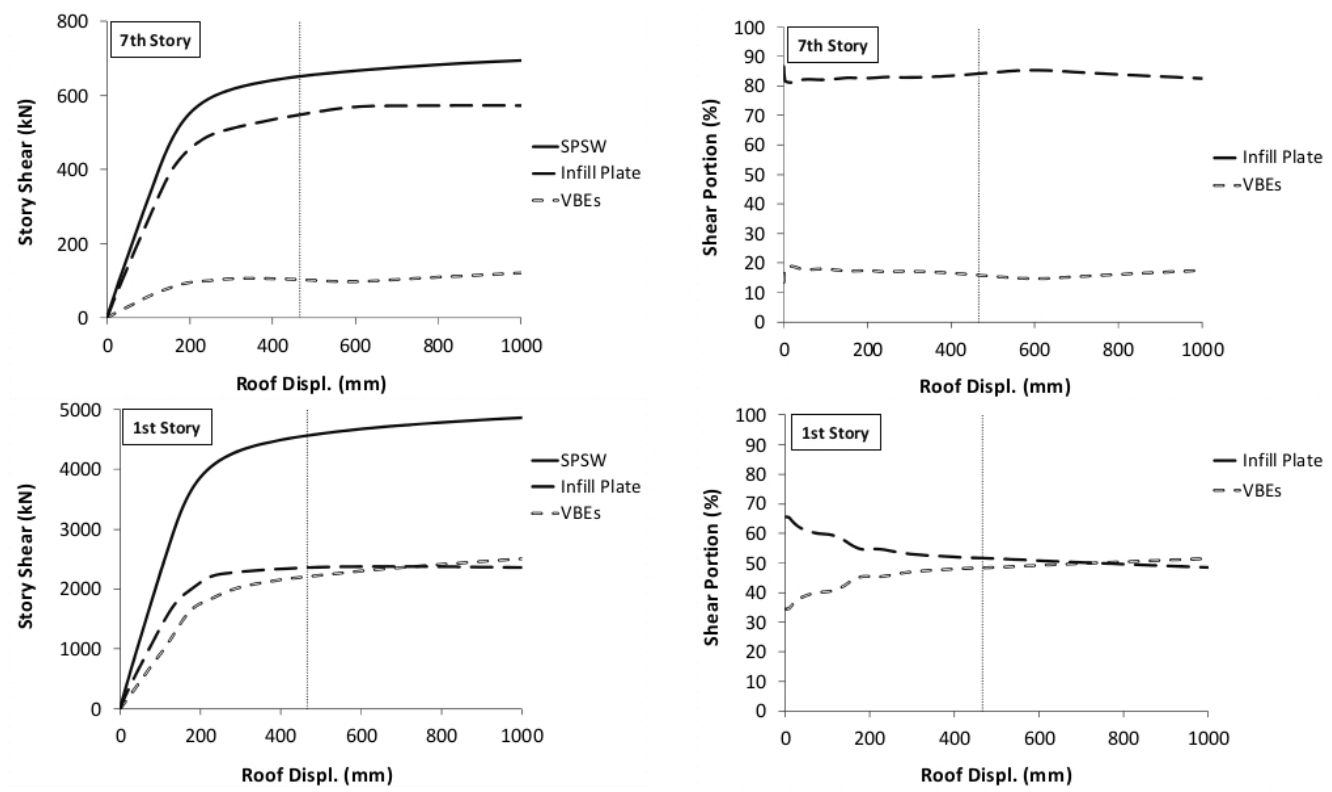

Fig. 10. Story shear and shear portion in the 7 -story frame under UL pattern 

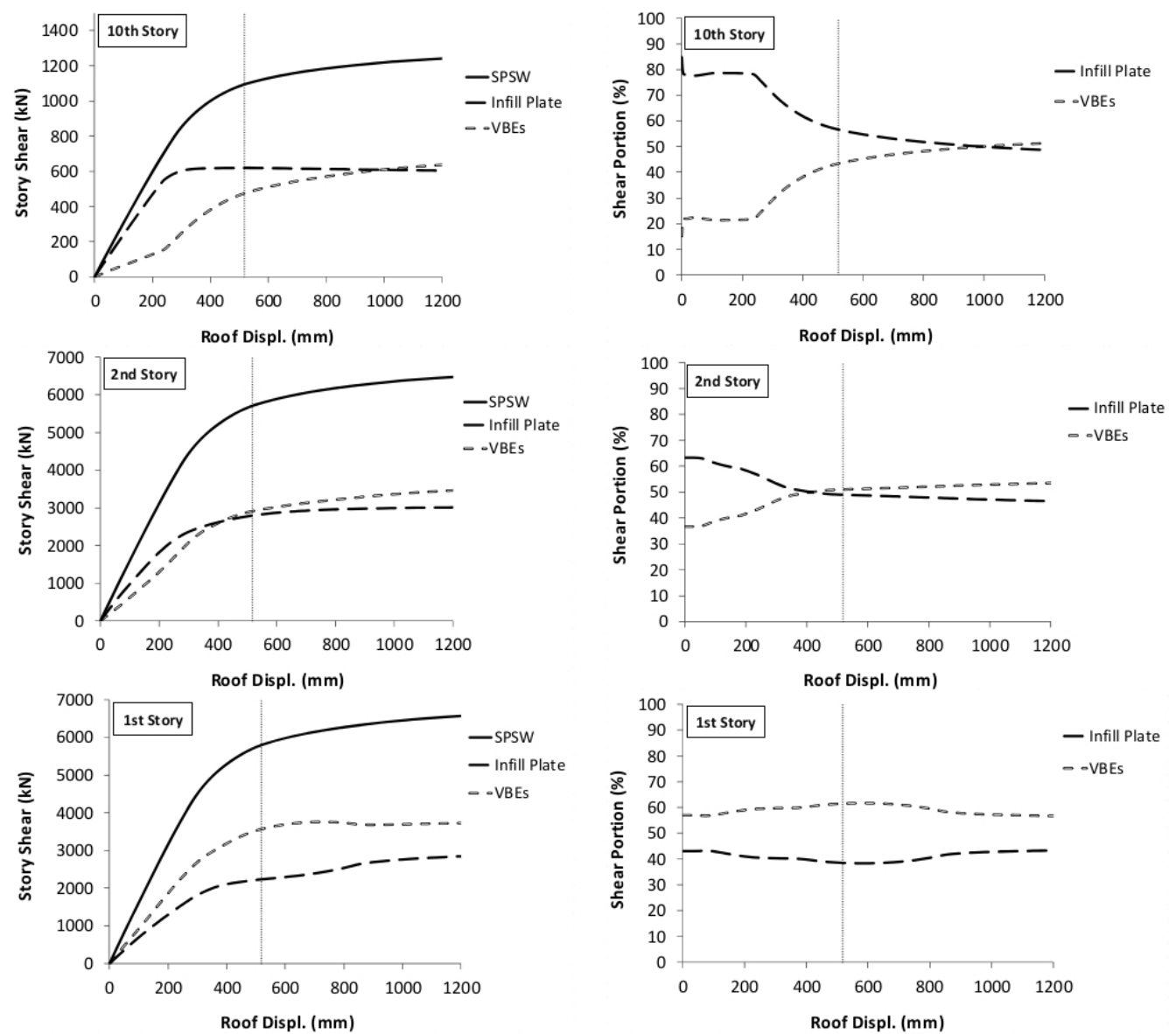

Fig. 11. Story shear and shear portion in the 10-story frame under TL pattern
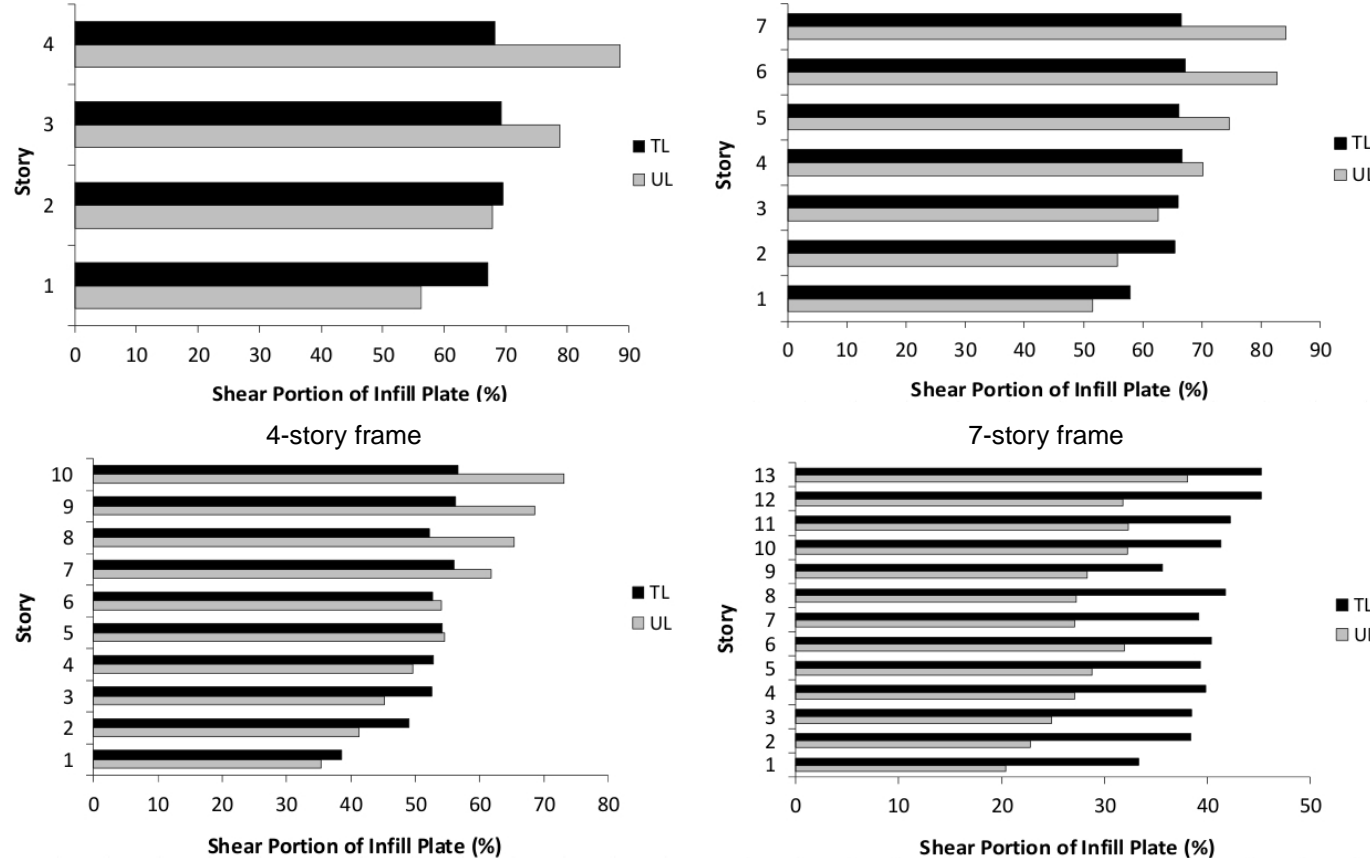

7-story frame

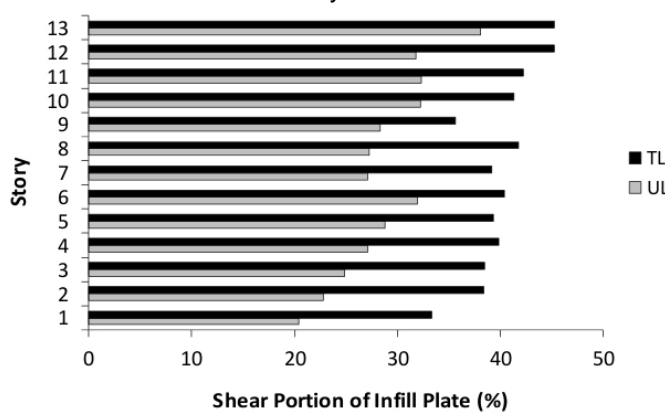

10-story frame

13-story frame

Fig. 12. Shear portion of infill plates at each story level at ultimate state 
sorbed most of the story shear. Under UL pattern, in all stories, most of the story shear was resisted by the VBEs throughout the loading.

The shear portion of infill plates at the ultimate state at every story level of the four considered frames is given in Fig. 12 . under both TL and UL patterns. As observed, the contribution of infill plate to the story shear is more in the upper stories. In addition, the story shear resisted by infill plates decreases as the height of SPSW frames increases. In the design procedure of SPSW frames, the contribution of VBEs is neglected; and infill plates are presumed to resist the full story shear. This assumption results in thicker infill plates, larger VBE sections, and thus greater shear capacity. Since the story shear increases with the number of story levels, and due to the fact that lower stories have greater shear, very thick infill plates and extra large VBE sections are required in the lower stories of high-rise frames. As a result, and in turn, the portion of shear absorbed by the VBEs becomes very large.

It should be reminded that the thickness of infill plates and the section properties of frame members in the considered frames are as designed, with no modifications for practical purposes. If, for any reason, the design sections are to be modified, a completely different set of results would be obtained. For example, in ref. [18], the sections of the first story VBEs were presumed for all stories. That assumption resulted in smaller contribution of infill plates in the upper stories.

\subsection{Ductility factor}

The ductility factor is defined as the ratio of the total displacement at the maximum load level to the elastic limit displacement ( $\mu=\Delta_{\max } / \Delta_{y}$, as indicated in Fig. 13 To calculate the yield displacement $\left(\Delta_{y}\right)$, the nonlinear pushover curve is replaced with an idealized bilinear curve as mentioned in FEMA-356 [15]. The ultimate displacement $\left(\Delta_{\max }\right)$ is defined at the instant of $2.5 \%$ drift angle.

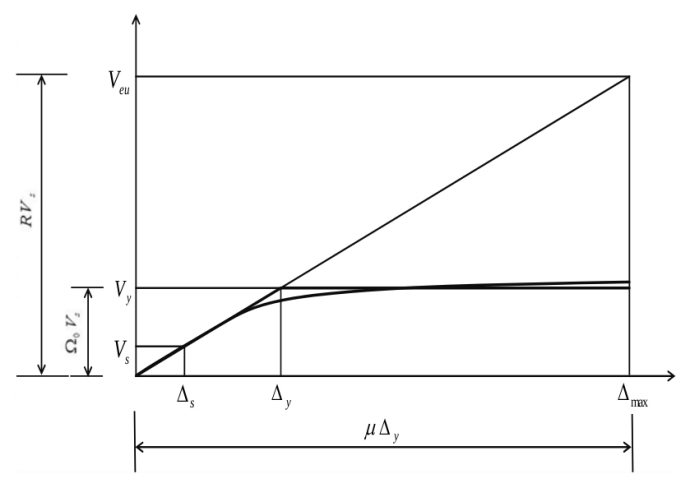

Fig. 13. Generic pushover curve

Fig. 14 shows the ductility factor of the considered frames, under both TL and UL patterns.

As shown, the ductility factor in the UL pattern is always more than the TL pattern. This is because that the stiffness of SPSW structure under UL is greater than those of the TL, which

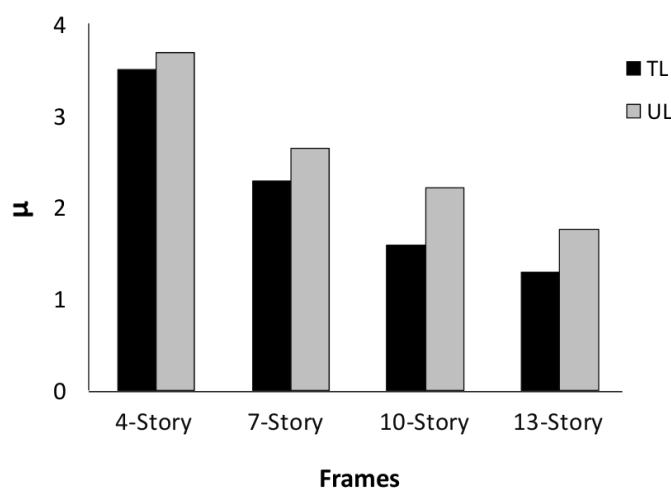

Fig. 14. The ductility factor

results in larger ultimate roof displacements. Results also show that the ductility decreases with the number of story levels.

The differential ductility factor for each story is given in Fig. 15. Under UL, ductility decreases from the lower stories upwards; but a somehow reverse pattern is observed under TL. In each loading pattern, the variation of ductility is in accordance with the yielded areas of infill plates, previously given in Fig. 8

\subsection{Response modification and overstrength factors}

The response modification factor $(R)$ and the overstrength factor $\left(\Omega_{0}\right)$ are respectively defined as the ratios $V_{e u} / V_{s}$ and $V_{y} / V_{s}$ as indicated in Fig. $13 \quad V_{e u}$ is the ultimate elastic base shear defined at the ultimate displacement $\left(\Delta_{\max }\right) . V_{y}$ is the base shear at the structural collapse level and $V_{s}$ is the design base shear. ASCE 7-10 [16] suggests $R=7$ and $\Omega_{0}=2$ for structures in which the SPSW is the only seismic force resisting system.

For the frames considered herein, the values of $R$ and $\Omega_{0}$ are given as in Fig. 16. The horizontal lines indicate thesuggested $R=7$ and $\Omega_{0}=2$ limits. Accordingly, both factors are larger in the UL pattern than in the TL pattern. The dependence of $\Omega_{0}$ on the lateral loading pattern was also mentioned in ref. [19].

Fig. 16 also shows that $R$ and $\Omega_{0}$ change considerably with the number of story levels. $R$ decreases with the number of stories. In taller frames, the deviation of $R$ from 7 is considerable in the TL pattern. Similar results were reported for chevron eccentrically braced frames in ref. [25] and dual moment resisting frames with buckling restrained braces in ref. [26]. On the other hand, $\Omega_{0}$ increases with the number of story levels. As explained in section 4.4 , very thick infill plates and extra large VBE sections are needed in the lower stories of high-rise frames. This results in extra shear capacity and thus greater overstrength factor in high-rise SPSW structures.

\subsection{Axial forces in VBEs}

The pushover analysis is a good mean to determine the realistic design forces in VBEs according to the capacity design requirements [2,20].

The axial demand of a VBE is highly dependent on the yielded areas of its adjacent infill plate. In the capacity design 

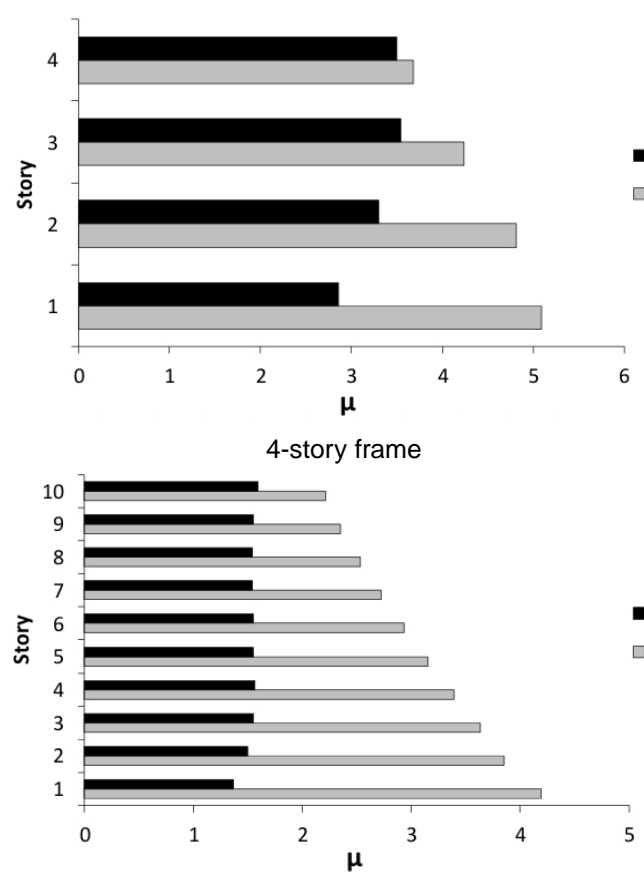

10-story frame

Fig. 15. Ductility factors for each story level

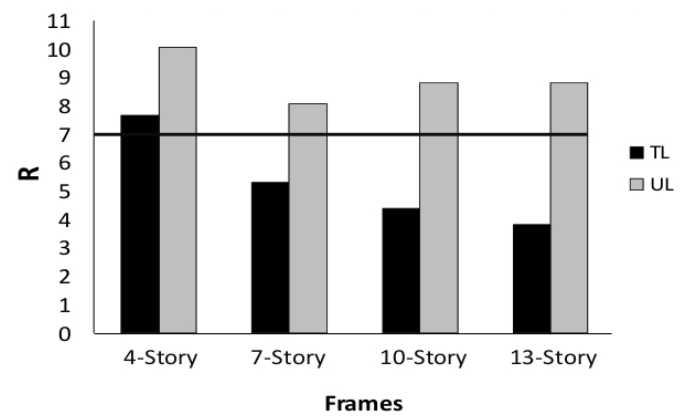

Response modification factors

Fig. 16. Response modification and overstrength factors

method, it is assumed that all infill plates yield fully and simultaneously. In references [27 28], however, it is stated that simultaneous full yielding of infill plates along the height of high-rise SPSWs is unlikely. The results of the nonlinear time history analyses presented in ref. [18] also show that in high-rise SPSW structures, the VBEs' axial demand is smaller than those predicted by the capacity design method.

For the considered frames, the variation of axial forces along the height of both left and right VBEs, obtained under TL and UL patterns at the ultimate state, is depicted in Fig. 17. The VBE axial forces $\left(P_{P}\right)$ are normalized by the axial forces calculated by the capacity design method $\left(P_{C D}\right)$. The vertical dotted lines in Fig. 17 represent the " $P_{P} / P_{C D}=1$ " limit (i.e. the axial force obtained in the pushover analysis be equal to the axial force calculated via the capacity design method). If $P_{P} / P_{C D}>1$, the axial design force should be increased to account for the excessive demand. In such situations, design of VBEs should be verified and revised accordingly. In situations where $P_{P} / P_{C D}<1$, it is possible to reduce the design axial forces which in turn,
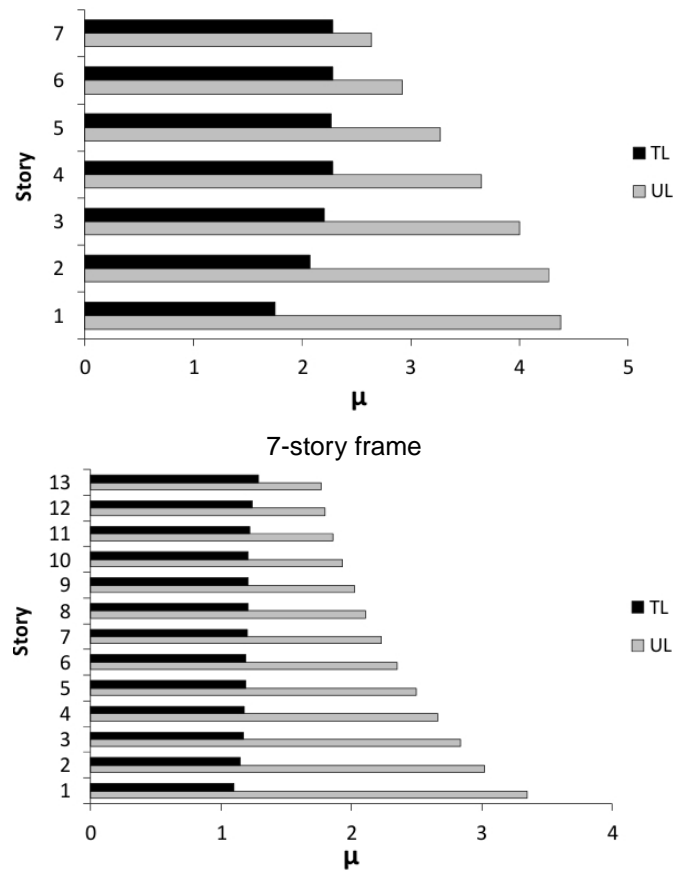

13-story frame

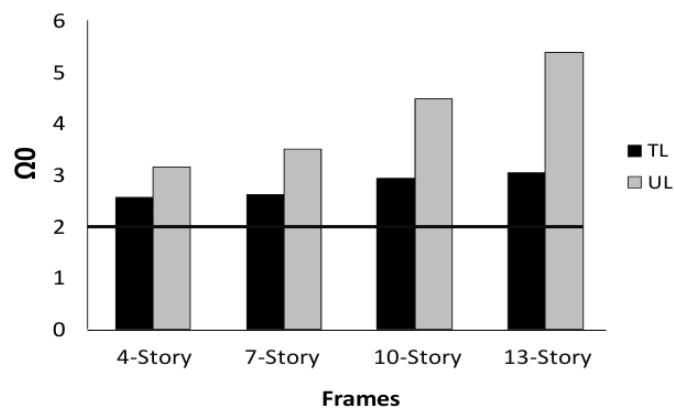

Overstrength factors

leads to smaller VBE design sections.

In order to read the results given in Fig. 17, it should be reminded that the design sections of the left and right VBEs must be similar to account for the cyclic nature of seismic loading; and design should also cover both TL and UL patterns. In the 4- and 7-story frames, the design sections of VBEs were governed by the left VBEs in all stories. As indicated in Fig. 17] the values of $P_{P} / P_{C D}$ in TL curves of the left VBEs are the highest amongst the four curves in each frame; and their values are greater than one. In other words, the axial forces obtained via the pushover analyses are greater than those calculated by the capacity design method. This can be attributed to large strain hardening in HBEs. According to the AISC-341 [2] requirements, the design plastic moments of HBEs were calculated for a strain hardening factor of 1.1; even though, the stress-strain characteristic of frame members' material shows higher values of strain hardening (see Fig. 3).

In the $1^{\text {st }}$ to $5^{\text {th }}$ stories of the 10 -story frame, the design sections of VBEs were governed by the left VBEs. In the $6^{\text {th }}$ to 


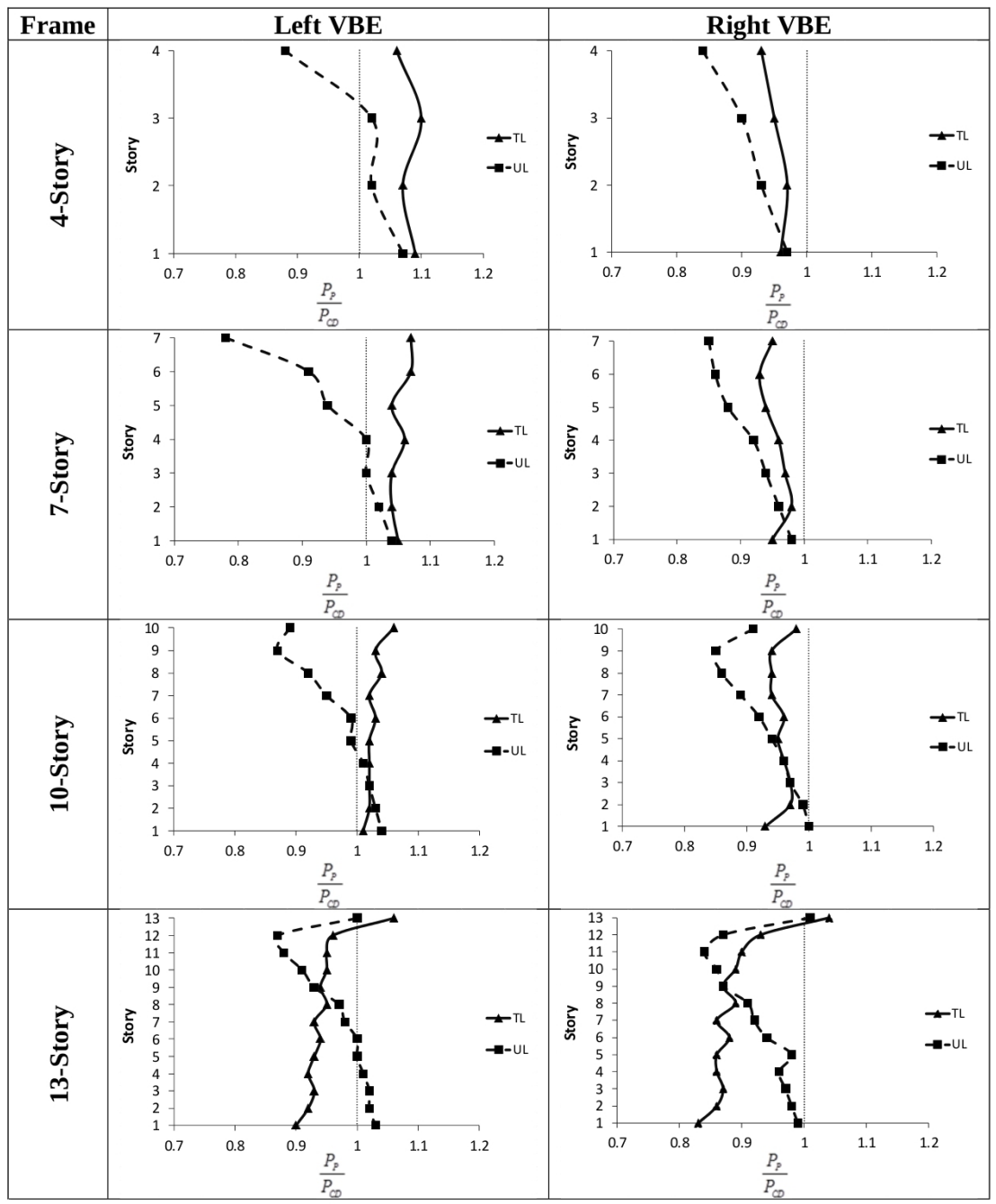

Fig. 17. The axial force of VBEs from pushover analyses normalized by the axial force calculated via the capacity design method

$10^{\text {th }}$ stories, however, the design sections were governed by the right VBEs. Furthermore, the ratio of $P_{P} / P_{C D}$ in the $6^{\text {th }}$ to $10^{\text {th }}$ stories are less than one; and thus, it is possible to reduce the design axial forces to those calculated via the pushover analysis under the TL pattern.

In the $1^{\text {st }}$ to $6^{\text {th }}$ stories of the 13 -story frame, the design sections of VBEs were governed by the left VBEs; and the rest by the right VBEs. Here too, it is possible to reduce the design axial forces of VBEs in the $7^{\text {th }}$ to $12^{\text {th }}$ stories.

As the number of story levels increases, the possibility of complete yielding of infill plates along the entire height of structure decreases. The yielded areas of infill plates in the $9^{\text {th }}$ to $12^{\text {th }}$ story of the 13-story frame under TL pattern at the ultimate state is presented as examples in Fig. 18. As indicated, infill plates did not fully yield in those stories; and therefore, the axial forces induced by infill plates on the corresponding VBEs could be reduced in comparison to the presumed design forces calculated by the capacity design method.

\section{Conclusions}

Pushover analyses were performed on five 4- to 13-story steel plate shear wall structures. The frames were designed according to the rules and specifications of AISC-341 and AISC-360; and analyzed under the two FEMA-356 recommended lateral load distribution patterns. One loading pattern was proportional to the shape of the fundamental mode, known as triangular loading (TL); and the other pattern was a uniform distribution in proportion to the total story mass of each story level; called uniform loading (UL). Based on the results obtained in this research, the following points are concluded:

- In comparison to the results obtained under TL pattern, the UL pattern provides higher lateral stiffness and ultimate load carrying capacity of SPSW frames. The discrepancy between the results of the two loading patterns increases with the height of SPSW frames.

- Yielding pattern of infill plates is quite different under the two loading patterns. Under TL pattern, the infill plates in upper stories yield more than the lower stories. Whereas under UL pattern, the infill plates in lower stories yield more than the upper ones.

- Under both TL and UL patterns, the infill plates in the upper stories contribute more in absorbing the story shear. On the other hand, the shear portion of infill plates decreases as the height of SPSW frames increases.

- In both loading patterns, the response modification factor 


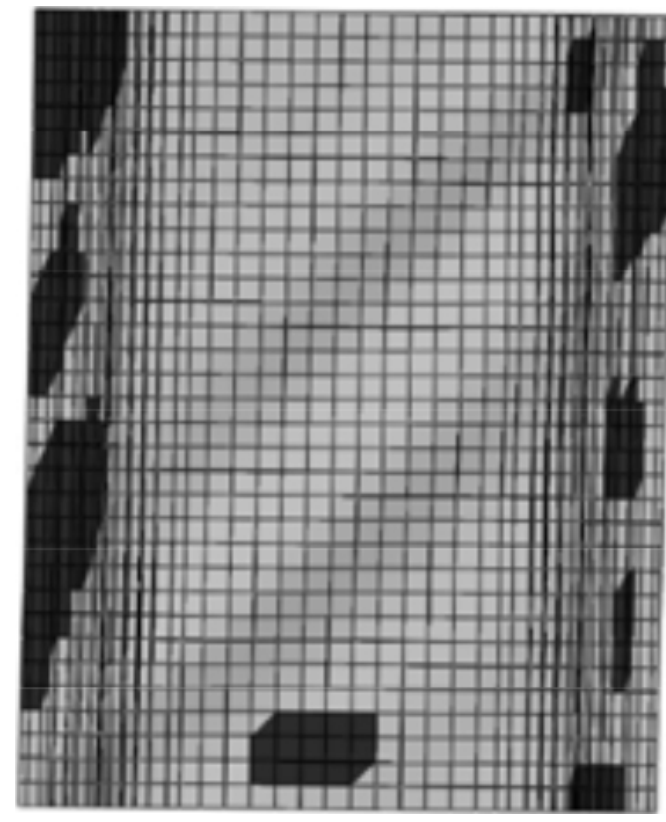

$12^{\text {th }}$ Story

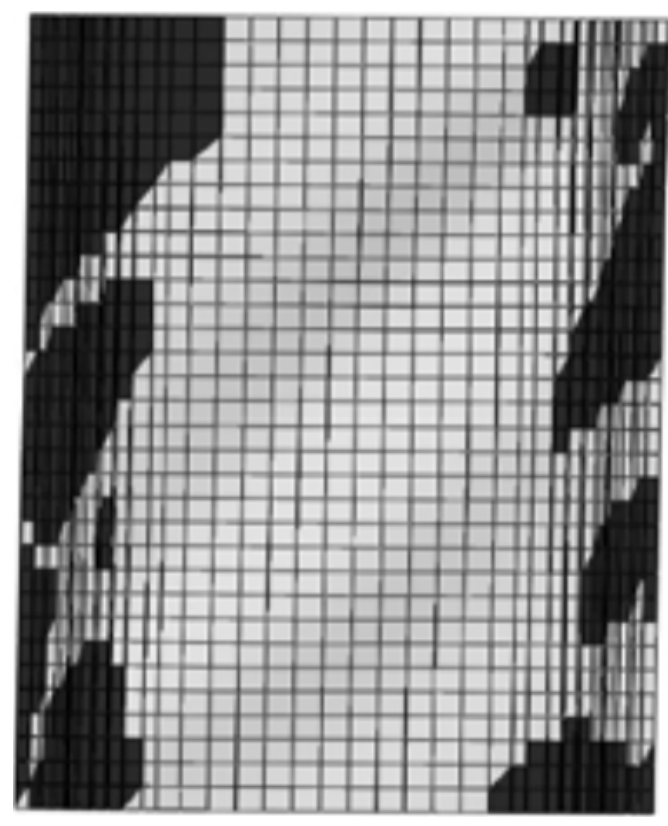

$10^{\text {th }}$ story

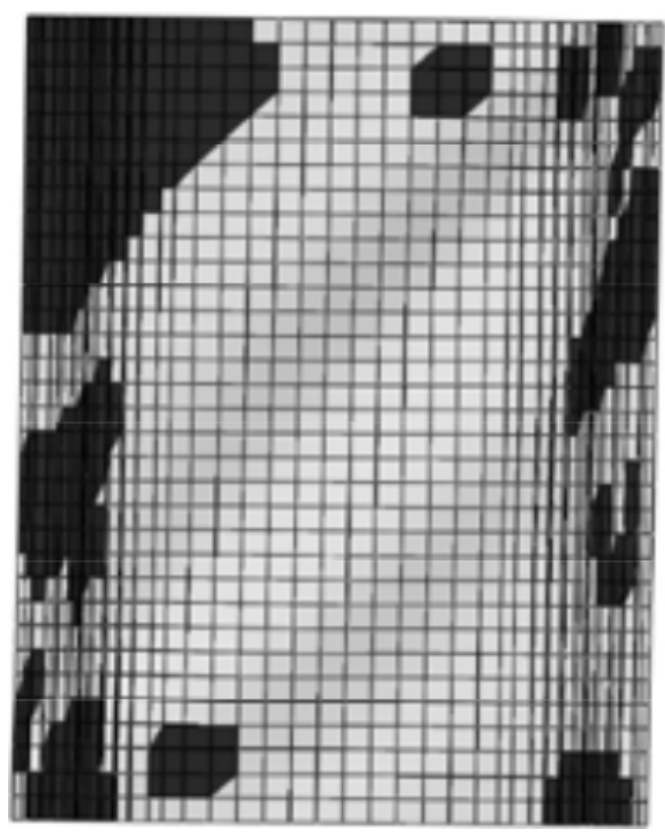

$11^{\text {th }}$ Story

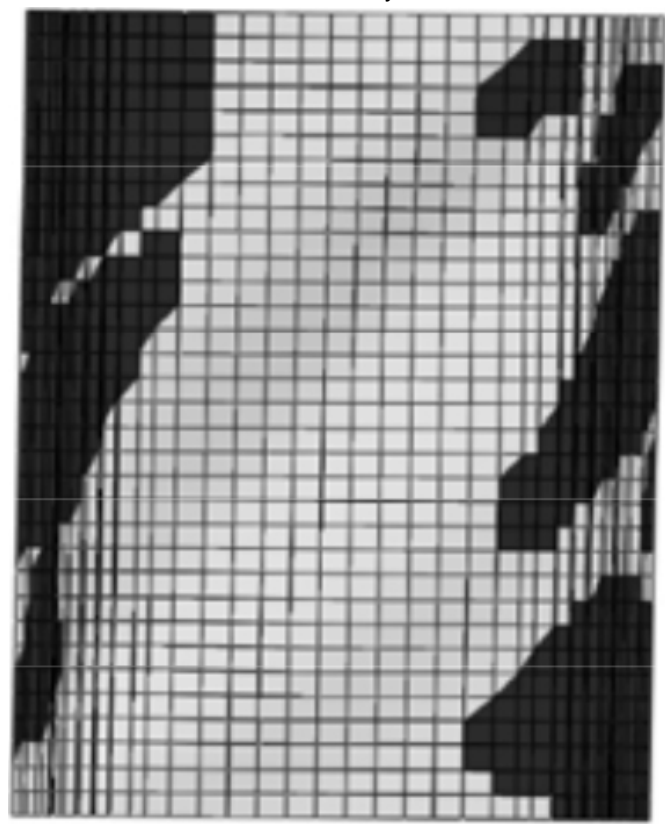

$9^{\text {th }}$ Story

Fig. 18. Yielded areas of infill plates at the ultimate state of the 13-story frame under TL pattern 
$(R)$ and the overstrength factor $\left(\Omega_{0}\right)$, respectively, decreases and increases with the number of story levels.

- In order to have a more realistic design of VBEs, it is required to consider the measured values of material strain hardening in calculating the design plastic moments of HBEs; rather than the general value of 1.1 recommended by the AISC-341.

- The predicted axial forces of the VBEs in the upper stories of high-rise frames via the pushover analysis are less than those calculated by the capacity design method. In such cases, it is possible to reduce the design sections of VBEs.

- Under uniform loading pattern, the ductility, story drift, and VBEs' axial force demand are mostly concentrated in the lower stories; whereas the triangular loading pattern predicts the response more homogenously along the height of SPSW frame.

\section{References}

1 Guidelines for cyclic seismic testing of components of steel structures, 1992. Report ATC-24.

2 Seismic provisions for structural steel buildings, American Institute of Steel Construction, (2010). AISC-341.

3 Shishkin JJ, Driver RG, Grondin GY, Analysis of steel plate shear walls using the modified strip model, Journal of Structural Engineering, ASCE, 135(11), (2009), 1357-1366, DOI 10.1061/(ASCE)ST.1943-541X.0000066

4 Kharrazi M, Prion H, Ventura C, Implementation of M-PFI method in design of steel plate walls, Journal of Constructional Steel Research, 64, (2008), 465-479, DOI 10.1016/j.jcsr.2007.09.005

5 Kulak GL, Laurie Kennedy DJ, Driver RG, Medhekar M, Behavior and design of steel plate shear walls, American Institute of Steel Construction, (2003).

6 Shishkin JJ, Driver RG, Grondin GY, Analysis of steel plate shear walls using the modified strip model, 2005. Structural Engineering Report No. 261.

7 Choi IR, Park HG, Ductility and energy dissipation capacity of sheardominated steel plate walls, Journal of Structural Engineer, ASCE, 134(9), (2008), 1495-1507, DOI 10.1061/(ASCE)0733-9445(2008)134:9(1495)

8 Park HG, Kwack JH, Jeon SW, Kim WK, Choi IR, Framed steel plate wall behavior under cyclic lateral loading, Journal of Structural Engineering, ASCE, 133(3), (2007), 378-388, DOI 10.1061/(ASCE)07339445(2007)133:3(378)

9 Inel M, Tjhin T, Aschheim AM, The significance of lateral load pattern in pushover analysis, $5^{\text {th }}$ National Conference on Earthquake Engineering, In:; Istanbul, Turkey, 2003-05-26.

10 Kalkan E, Kunnath S K, Assessment of current nonlinear static procedures for seismic evaluation of buildings, Engineering Structures, 29(3), (2007), 305-316, DOI 10.1016/j.engstruct.2006.04.012

11 Mohammad Agha H, Yingmin L, Asal Salih O, Al-Jbori A, Nonlinear Performance of a Ten-story Reinforced Concrete Special Moment Resisting Frame (SMRF), (China, 2008-10-12).

12 Oguz S, Evaluation of pushover analysis procedures for frame structures; Turkey, 2005.

13 Antoniou S, Rovithakis A, Pinho R, Development and verification of a fully adaptive pushover procedure, $12^{\text {th }}$ European Conference on Earthquake Engineering, In:; London, UK, 2002-09-09.

14 Serror MH, El-Esnaw NA, Abo-Dagher RF, Effect of pushover load pattern on seismic responses of RC frame buildings, Journal of American Science, 8, (2012), 438-447.

15 Pre standard and commentary for the seismic rehabilitation of buildings; Washington, D. C., 2000. FEMA-356.

16 Minimum design loads for buildings and other structures; Reston, Virginia, 2010. ASCE-7.
17 Behbahanifard MR, Grondin GY, Elwi AE, Experimental and numerical investigation of steel plate shear wall; Edmonton, Alberta, Canada, 2003. Structural Engineering Report No. 254.

18 Berman JW, Seismic behavior of code designed steel plate shear walls, Engineering Structures, 33, (2011), 230-244, DOI 10.1016/j.engstruct.2010.10.015

19 Kurban CO, Topkaya C, A numerical study on response modification, overstrength, and displacement amplification factors for steel plate shear wall systems, Earthquake Engineering Structures, 38, (2009), 497-516, DOI 10.1002/eqe.866

20 Steel design guide 20; Chicago, Illinois, 2007. AISC-820.

21 Specification for structural steel buildings; Chicago, Illinois, 2010. AISC360.

22 ABAQUS theory manual; USA, 2010.

23 Habashi HR, Alinia MM, Characteristics of the wall-frame interaction in steel plate shear walls, Journal of Constructional Steel Research, 66, (2010), 150-158, DOI 10.1016/j.jcsr.2009.09.004

24 Driver RG, Kulak GL, Laurie Kennedy DJ, Elwi AE, Cyclic test of four-story steel plate shear wall, Journal of Structural Engineering, 124(2), (1998), 112-120.

25 Abdollahzadeh G, Maleki Kambakhs A, Height effect on response modification factor of open chevron eccentrically braced frames, Iranian Journal of Energy and Environment, 3, (2012), 72-77, DOI 10.5829/idosi.ijee.2012.03.01.2559

26 Abdollahzadeh G, Banihashemi MR, Elkaee S, Esmaeelnia Amiri M, Response modification factor of dual moment-resistant frame with buckling restrained brace (BRB), 15 ${ }^{\text {th }}$ World Conference on Earthquake Engineering, In:; Lisbon, Portugal, 2012-09-24.

27 Berman JW, Bruneau M, Capacity design of vertical boundary elements in steel plate shear walls, Engineering Journal, (2008), 57-71. AISC.

28 Berman JW, Lowes LN, Okazaki T, Bruneau M, Tsai KC, Driver RG, Sabelli R, Research needs and future directions for steel plate shear walls, American Society of Civil Engineers, (2008). ASCE. 